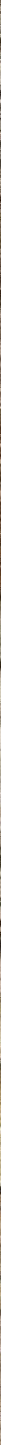

\title{
CRAFTING IDENTITIES
}

\author{
ARTISAN CULTURE IN LONDON, $c$. 1550-1640
}

Jasmine Kilburn-Toppin 


\section{Crafting identities}

\section{MANCHESTER 1824}

Manchester University Press 
To buy or to find out more about the books currently available in this series, please go to: https:// manchesteruniversitypress.co.uk/series/ studies-in-design-and-material-culture/

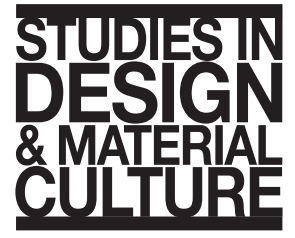

general editors Elizabeth Currie

Sally-Anne Huxtable and

James Ryan

founding editor

Paul Greenhalgh 


\title{
Crafting identities
}

Artisan culture in London, c. 1550-1640

\author{
Jasmine Kilburn-Toppin
}

Manchester University Press 
Copyright () Manchester University Press 2021

The right of Jasmine Kilburn-Toppin to be identified as the author of this work has been asserted by them in accordance with the Copyright, Designs and Patents Act 1988.

Published by Manchester University Press

Altrincham Street, Manchester M1 7JA

www.manchesteruniversitypress.co.uk

British Library Cataloguing-in-Publication Data

A catalogue record for this book is available from the British Library

ISBN 9781526147707 hardback

First published 2021

The publisher has no responsibility for the persistence or accuracy of URLs for any external or third-party internet websites referred to in this book, and does not guarantee that any content on such websites is, or will remain, accurate or appropriate.

Cover image:

'Christ in the Carpenters' Shop',

Carpenters' Company wall painting

c. 1562. Reproduced with kind

permission of the Carpenters'

Company.

Typeset

by New Best-set Typesetters Ltd 